\title{
APPLICATION OF ANALYTICAL NETWORK PROCESS IN FORECASTING AUTOMOBILE SALES OF FIAT $500 \mathrm{~L}$
}

\author{
Predrag Mimovic* \\ Faculty of Economics, University of Kragujevac, Kragujevac, Serbia
}

This paper describes the application of Analytic Network Process (ANP) in the modeling and analysis of various factors and the impact on the forecasting processes in situations when there is a need for the integration of contextual information, which is the result of sudden and unpredictable changes in the environment in which the company operates. The model is applied on a sample in forecasting the sale of a new model automobile Fiat $500 \mathrm{~L}$, and is based on the professional knowledge of experts in automobile market trends, the actual current and projected trends in automobile sale and subjective evaluations of the authors, and in the context of the global economic crisis which significantly affects automobile sale in the world market.

Keywords: sale, forecasting, automotive industry, the analytical network process

JEL Classification: C51, C53, D81,E27, F47

\section{INTRODUCTION}

Considering that the global economy operates in conditions of a high risk and uncertainty, caused by the global economic crisis, the forecasting of automobile sale, especially of new models, presents a complex, multidimensional and multi-criteria problem, which also requires a methodology of an appropriate level of complexity.

The research subject in this paper deals with the possibility of using the Analytic Network Process (ANP), as a multi-criteria method for decision support

\footnotetext{
* Correspondence to: P. Mimovic, Faculty of Economics, University of Kragujevac, Dj. Pucara 3, 34000 Kragujevac, Serbia; e-mail:mimovicp@kg.ac.rs
}

Review paper doi: $10.5937 /$ ekonhor1203165M 
industry could contribute to a better understanding of its functioning in the global environment, especially in times of a crisis and recession and bearing in mind their interdependence.

When it comes to the sales forecasting of new products, the lack of historical information favors the use of qualitative forecasting methods. The important, essential advantage of qualitative forecasting methods in relation to quantitative forecasting methods lies in their potential to forecast changes that may occur in demand for a new product, and, implicitly, in the range of its sale.

Although the ANP model is based on subjective assessments characterized by a successful application in many areas of forecasting, the ability to rapidly incorporate feedback and a possibility of simple comparison to actual results. The structure of the paper is organized in the following way: in the second part which consists of two sections, a review of the literature concerning the problem of forecasting automobile sale has been given, along with a brief description of the processed problems and the used forecast methods, as well as a review of the relevant references relating to the application of the Analytic Network Process, with a special overview on the forecasting area, whose theoretical and methodological framework for solving the analyzed forecasting problem is defined. In the third part of the paper, firstly, the ANP method is described and then applied to a specific case study. The Analytical Network Process in the literature is suggested as a solution for large, dynamic and complex problems of multiple criteria decision-making, such as the strategic planning of organizational resources, the evaluation of strategic alternatives and an opportunity of introducing new manufacturing technologies. These problems include numerous, both quantitative and qualitative factors, then many interactive attributes (economic, social, political, cultural, etc.) and complex relations between them. All these problems mostly rely on measurement and relations in the process of multi-criteria decision-making and are based on the estimation of managerial preferences. One such problem is forecasting, which includes a number of interrelated and often conflicted factors and dependencies that need to be taken into account in order to make an optimal business decision.
Finally, the model results are presented together with a postoptimal analysis, as well as the conclusion, with possible indications for a future research.

\section{LITERATURE REVIEW}

Due to the possible implications for consumption and the economy in general, forecasting the sale of durable goods such as automobiles has a great significance, especially concerning that the automotive industry has the key role in many economies and presents their main driving force and is the generator of their economic growth and development. Demand for automobiles significantly affects the trends in travel and tourism, the development of the transportation infrastructure and residential patterns (Ebu Eisheh \& Mannering, 2002), and all these activities contribute to economic expansion and the opening of the new jobs. On the other hand, economic expansion puts pressure on politicians, economists, urban planners and traffic engineers, to be aware of the trends in demand for automobiles and that incorporate the feedback from them into their plans and projects. Buying an automobile is a critical consumer decision influenced by many psychological, sociological and economic factors, in both developed and developing countries. (Abu Eisheh \& Mannering, 2002).

In an attempt to better understand the movement of the automotive market and the future of the automotive industry, recent studies and the analysis cite three key factors determining the volume of automobile sale: the purchasing capacity of the population, the borrowing capacity and motivation for buying automobiles, also emphasizing the factor of the so-called restrained demand, which should be taken into account during forecasting automobile sale, especially after a period of a major falling sale caused by global crises (Plache, 2011). The automotive market has a large part on the market for consumer durable goods, and companies that manufacture automobiles cannot eliminate the need to forecast the sale of new models (Kahn, 2002), regardless of the uncertainty present in their development and marketing and objective constraints, which, in addition to unrealistic expectations, often lead to misjudgments and great losses. In his automotive 
market research, Karlson and Umble (1980) forecast demand for automobiles in the period from 1979 to 1983 by classifying automobiles into five categories: sub-compact, compact, intermediate, standard and luxury. The authors tried to establish the nature of the relations between gasoline prices and other relevant factors and the automobile sale, concluding that the sale of compact vehicles grew faster (from 35 to 45 percent) than the sale of other types of automobiles. They also established the fact that the economic conditions were the main determinant of a future automobile sale. The study indicated the dependence on the gasoline prices and automobile sales. However, the study was limited to two independent variables in an attempt to forecast the sale during a difficult political period (the hostage crisis in Iran and the oil embargo). For the same reason, Harris (1986) also analyzed the impact of certain economic variables on the automobile sale and found a significant correlation between demand and some economic variables. Garcia-Ferrer et al (1997), use the ARIMA model to forecast automobile sale, in an effort to evaluate the performance of different forecast methods. The model of the National Road Traffic Forecasts (NRTF) Romilly (1995) includes a model based on the household and explanatory models. Both models use a combination of time series involving causal variables. The multi-criteria approach in forecasting sale was suggested by Chang et al (2007), through the development of fuzzy neural networks, Kuo (2001) and Thomaseo \& Fiordaliso (2006), which are using clusterization and essence for forecasting the complexity of the environment.

\section{Review of the ANP applications}

The Analytical Network Process (Saaty, 2001), as an extension of the Analytical Hierarchy Process (Saaty, 2010), can be used in solving the problem of choosing under the conditions of uncertainty or as a forecasting instrument. The problem of choice usually involves the preference evaluation of the alternative courses of action, while forecasting using the AHP/ANP focuses on performing the relative distribution of probable future outcomes. These forecasts are then used when the alternative courses of action are evaluated. The review of the ANP applications published in scientific journals (Graph 1) shows that the largest number of these applications were dedicated to solving the problem of strategic decision-making (28\%) (mainly the problem of the evaluation and selection of optimal business strategies and supply-chain strategies), and to a lesser extent to the resolving of political problems and conflicts between individual countries and companies, too.

The successful application of the Analytic Hierarchy Process (AHP) and their extensions, the Analytical Network Process (ANP) in economic forecasting was demonstrated by Saaty (2001), Gholam-Nezhad (1995), Saaty \& Gholam-Nezhad (1981), Blair et al (1987), Blair \& Saaty (2010), Saaty (2005), Niemira \& Saaty (2004), Yüksel (2005), Azis (2010), Voulgaridou et al (2009) an so on. In support of the AHP application in forecasting, the emphasized AHP advantages reflected in the ease of use and a great possibility of an assessment specification, performed by the consistency test. Saaty and Vargas (1991) analyze the application of the AHP in forecasting oil prices and forecasting exchange rates.

In addition, the Analytical Network Process has proved very successful in ranking and selecting projects, as demonstrated by Meade \& Presley (2002), as well as Lee \& Kim (2000), then in strategic decision-making, Sarkis (2003) and production planning Karsak et al (2002), optimal planning, Momoh \& Zhu (2003) etc. A

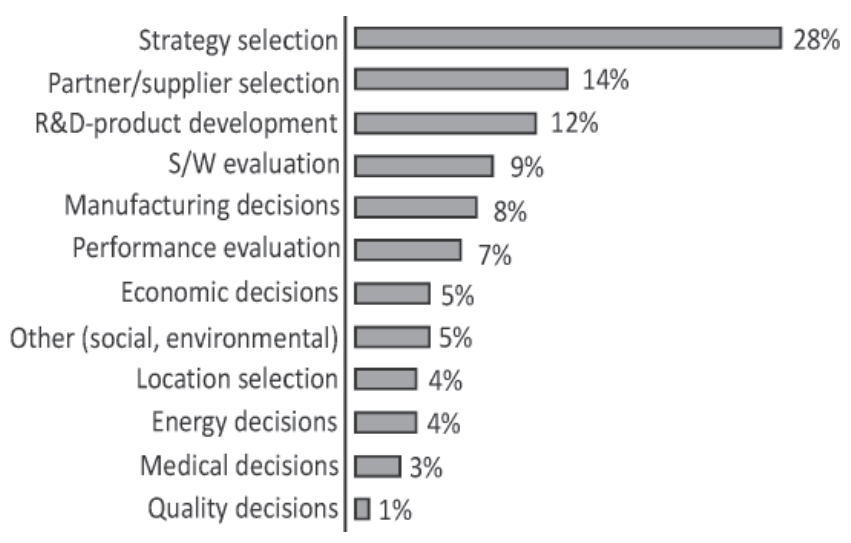

Graph 1 Viewing ANP applications

Source: Voulgaridou et al 2009, 40 
good review of AHP applications is given by Vaidya \& Kumar (2006). Voulgaridou et al (2009) demonstrate the use of the ANP in forecasting the sale of a new product, emphasizing the multiple criteria nature of the problem and the difference between sales forecasts in general and new product sales forecasts, which characterizes a limited amount of information, time available for an analysis and uncertainty in terms of the market response to such a new product.

\section{METHODOLOGY}

\section{Analytic Network Process}

The Analytical Network Process (ANP) is a method for decision support, developed by Thomas Saaty (2001), and allowing the involvement, quantification and objectification of all relevant, tangible and intangible factors in the decision-making process, as well as all the existing influences between decision criteria and alternatives. (Jharkharia \& Shankar, 2007). Generalizing the access of supermatrice, introduced in the AHP concept, the ANP allows interactions and feedback within and between the components of the model: in clusters (the inner dependence) and between clusters (the outer dependence). This feedback successfully includes complex relations, especially in the cases of risks and uncertainties. An ANP model consists of two parts. The first part consists of a hierarchical control or a network of criteria and sub-criteria controlling interactions in the studied system. The second part is the influence network, amongst the elements and clusters, whereby one ANP model can have one or more networks. Furthermore, the problem is often studied through a control hierarchy or a system which consists of benefits, costs, opportunities and risk. The synthesized results of the four control systems are combined by calculating the ratio between a product's benefits and possibilities and such a product's costs and risks in order to determine the best outcome.

The procedure of applying an ANP model of decisionmaking is carried out in five steps (Saaty, 2001):

- the decomposition of the problem - A decision problem is decomposed into its main components.
- the cluster formation for the evaluation - After defining the decision-making objectives, it is also necessary to generate clusters for the evaluation purpose by a criterion, sub-criterion (if it is possible) and cluster alternative.

- the structuring of the ANP model - The ANP is applied to different decision-making problems in the field of marketing, health, politics, military issues, society, predictions, etc. Their accuracy of forecasting proved in impressive applications in the field of economic trends, sports events and other events, whose outcome became known later.

- a paired comparison and prioritization - In this step, it is necessary to compare the pairs of elements of decision-making as well as the synthesis of priorities for all the alternatives. When such a paired comparison in the ANP model is made, questions are formulated in terms of domination or an impact, which is the central concept in the application of an AHP/ANP methodology. If a registry element is known, which of the two elements being compared in relation to it have a greater impact (it is more dominant) in comparison to that registry criteria? Or, in the case of an existing feedback, which of these two elements is under a higher influence of the registry criteria? The estimations are made by a fundamental scale 1-9 (Table 1), which the comparative study showed simulate human thinking most adequately.

- the sensitivity analysis of the solution - It is finally possible to make a decision and carry out a sensitivity analysis in terms of the impact which, according to the importance of some criteria or subcriteria, a final outcome has on a given solution; it is also possible to determine how big or small these indicators are through an analysis.

\section{Problem description and the construction of ANP model}

The model of the Analytical Network Process is applied to the problem of forecasting a sale for a new automobile model Fiat $500 \mathrm{~L}$. As they say in FIAT, the model $500 \mathrm{~L}$ combines the inherent characteristics of the different classes of automobiles, with an aim to 
Table 1 The scale of relative significance 1-9

\begin{tabular}{|c|c|c|}
\hline $\begin{array}{l}\text { Intensity of } \\
\text { Importance }\end{array}$ & Definition & Explanation \\
\hline 1 & Equal Importance & Two activities contribute equally to the objective \\
\hline 3 & Moderate importance & Experience and judgment slightly favor one activity over another \\
\hline 5 & Strong importance & Experience and judgment strongly favor one activity over another \\
\hline 7 & $\begin{array}{l}\text { Very strong or demon- } \\
\text { strated importance }\end{array}$ & $\begin{array}{l}\text { An activity is favored very strongly over another; its dominance demonstrated } \\
\text { in practice }\end{array}$ \\
\hline 9 & Extreme importance & $\begin{array}{l}\text { The evidence favoring one activity over another is of the highest possible } \\
\text { order of affirmation }\end{array}$ \\
\hline $2,4,6,8$ & $\begin{array}{l}\text { Mean values between } \\
\text { two adjacent esti- } \\
\text { mates }\end{array}$ & When compromise is needed \\
\hline $\begin{array}{l}\text { Reciprocals } \\
\text { of above }\end{array}$ & $\begin{array}{l}\text { A reasonable assump- } \\
\text { tion }\end{array}$ & $\begin{array}{l}\text { If activity } i \text { has one of the above nonzero numbers assigned to it when com- } \\
\text { pared with activity } j \text {, then } j \text { has the reciprocal value when compared with } i\end{array}$ \\
\hline
\end{tabular}

Source: Saaty \& Kearns 1985, 27

offer a distinctive and versatile vehicle that would be an alternative to the traditional models of the $\mathrm{B}$ and $C$ classes. The label "L" summarizes the three key dimensions, which represent a step forward in relation to the model FIAT 500: the size (Large) i.e. a large, functional and efficient space, light (Lightness), the use of friendly and ecological technologies making life easier and better, and adjustable surrounding (Loft), design allowing it to live a life to the fullest. The estimated sale of the FGA (Fiat Group Automobiles), contained in the plan presented by Sergio Marchionne, executive director of Fiat Corporation, was 2.7 million vehicles in 2012, 3.4 million vehicles in 2013 and 3.8 million in 2014. The main target markets for 2014 are the European one, with the expected sales of 2.15 million passenger and commercial vehicles; Latin America with the expected 1.125 million vehicles; Turkey, with 90,000 vehicles; China with 300,000 vehicles ( $2 \%$ market share); India, with 130,000 vehicles ( $5 \%$ market share) and 105,000 vehicles (Fiat and Alfa Romeo) that sold in the United States, produced by Crysler.

In mid-2012, at the Geneva Motor Show, Fiat introduced a new model, Fiat $500 \mathrm{~L}$, which will serially be produced in the city of Kragujevac, in the Republic of Serbia. The intention of the Turin automobile giant was to improve its position by launching this model in the
U.S. market, where the sale of the previous model 500 does not go according to the plan and where FIAT has unsuccessfully been trying to make a breakthrough for decades. Probably, the reasons for the failure of the model " 500 " lie primarily in their unrealistic expectations, considering the poor indicators of the world economy inevitably influencing the automotive industry, too; among them, there are, however, as it turned out, FIAT's organizational problems, such as an inadequate dealer network, delays in production, a delayed marketing campaign and a poor security rating, which proved to be the key issues of such a relative failure of the Fiat 500 model in the U.S. market. Let us remind you that the planned production of the Fiat 500 L model, initially planned $25000-35000$ vehicles per year, with the expectation that, in 2013, the number of those vehicles will increase to a total of 150,000 or even 200,000 vehicles. Considering also the fact that the sale of the older FIAT 500 model had primarily been forecast to be of 50,000 vehicles per year and that the actually accomplished sale was 20,000 vehicles, the forecasting of the sale of the new model clearly cannot be based on the expected or projected trends, especially when having in mind the organizational problems FIAT is being faced with, as well as the sensitivity of the automotive industry to global economic trends. The 
product range of passenger and commercial vehicles of the FIAT Group, ending June 2012, and in a relation to the same period in 2011, recorded an absolute decline in sale from 929,366 vehicles to 839,754 vehicles, which is a decrease of $9.64 \%$ (Table 2). On the other hand, the estimated automobile sale for the period from 2011 to 2015 (Graph 2), as well as the forecasting of the sale of the world's eight largest automakers for August 2012 (Table 3), are indicative of optimism in the assessment, which could be explained by positive economic trends in the U.S., increasing demand in China and India and the expectation that these trends will continue in the future, which cannot be ignored, either.

Starting from the given theoretical assumptions and the description of the problem, as well as the real situation in the environment, the appropriate ANP model forms with the structure presented by ANP network clusters, elements and the impact between them, whose validity has been verified, are based on expert analyses (available on the Internet):

- The ENVIRONMENT Cluster, which includes external factors that may affect the sale of vehicles

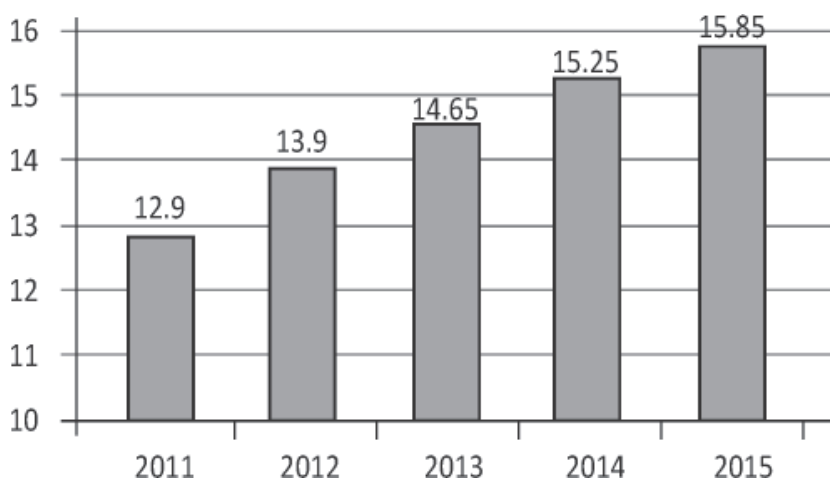

Graph 2 Prediction of car sales in the 2011-2015

Source: http://www.edmunds.com

including: customers, competition, the global financial crisis and technology. When FIAT $500 \mathrm{~L}$ starts being sold at the beginning of the year 2013, as announced, it will have a direct competitor on the Mini-Cauntr yman model, for which it has been announced that it will be similar in size, and will have $20 \mathrm{ks}$ more.

Table 2 Navigating monthly sales of passenger and commercial vehicles of the FIAT group, including the second quarter of the year 2012.

\begin{tabular}{|c|c|c|c|c|c|c|c|c|c|c|c|c|c|}
\hline 2012 & Jan & Feb & Mar & Apr & May & Jun & Jul & Aug & Sep & Oct & Nov & Dec & \\
\hline Italy & 39.716 & 36.237 & 35.279 & 40.154 & 45.849 & 38.882 & & & & & & 236.117 & $-20.29 \%$ \\
\hline France & 4.963 & 5.574 & 6.444 & 5.024 & 5.026 & 3.179 & & & & & & 33.210 & $-25.62 \%$ \\
\hline Germany & 5.849 & 6.055 & 9.291 & 8.370 & 9.078 & 8.595 & & & & & & 47.238 & $-9.29 \%$ \\
\hline Spain & 1.514 & 2.340 & 2.706 & 1.961 & 2.150 & 2.588 & & & & & & 13.259 & $1.89 \%$ \\
\hline UK & 3.522 & 1.724 & 10.904 & 4.529 & 4.923 & 5.647 & & & & & & 31.249 & $5.52 \%$ \\
\hline Europe & 11.068 & 11.730 & 13.283 & 12.562 & 12.344 & 14.580 & & & & & & 75.567 & $-18.18 \%$ \\
\hline Brazil & 42.366 & 43.393 & 51.109 & 41.430 & 45.865 & 63.530 & & & & & & 287.693 & $-0.58 \%$ \\
\hline Russia & 1.008 & 1.002 & 1.154 & 144 & 269 & 476 & & & & & & 4.053 & $-72.02 \%$ \\
\hline India & 2.101 & 1.704 & 1.415 & 1.000 & 1.002 & 805 & & & & & & 8.027 & $-30.71 \%$ \\
\hline Turkey & 1.335 & 2.866 & 3.966 & 4.010 & 4.663 & 4.431 & & & & & & 21.271 & $-30.13 \%$ \\
\hline Mexico & 520 & 238 & 395 & 319 & 460 & 477 & & & & & & 2.409 & $144.07 \%$ \\
\hline Argentina & 12.726 & 6.050 & 8.740 & 6.657 & 8.184 & 6.407 & & & & & & 48.761 & $12.97 \%$ \\
\hline Japan & 376 & 762 & 1.345 & 652 & 828 & 1.307 & & & & & & 5.270 & $35.06 \%$ \\
\hline USA & 1.911 & 3.227 & 3.712 & 3.849 & 4.003 & 4.004 & & & & & & 20.706 & $318.81 \%$ \\
\hline Canada & 321 & 533 & 1.207 & 1.211 & 810 & 839 & & & & & & 4.921 & $92.23 \%$ \\
\hline
\end{tabular}

Source: http://www.carsitaly.net/fiat_auto.htm 
Table 3 Estimated sales of the world's eight largest automakers in August 2012

\begin{tabular}{lrcc}
\hline Manufacturer & $\begin{array}{c}\text { August 2012 } \\
\text { Forecast }\end{array}$ & $\begin{array}{c}\text { \% Change } \\
\text { vs. } \\
\text { July 2012 }\end{array}$ & $\begin{array}{c}\text { \% Change vs. } \\
\text { August 2011 }\end{array}$ \\
\hline Chrysler & 142,593 & $13.1 \%$ & $9.6 \%$ \\
Ford & 191,456 & $10.4 \%$ & $9.5 \%$ \\
GM & 227,087 & $12.8 \%$ & $3.9 \%$ \\
Honda & 133,458 & $14.1 \%$ & $62.1 \%$ \\
Hyundai/Kia & 117,212 & $6.5 \%$ & $17.6 \%$ \\
Nissan & 97,022 & $-1.3 \%$ & $6.0 \%$ \\
Toyota & 182,896 & $10.9 \%$ & $41.3 \%$ \\
Volkswagen & 47,069 & $-3.4 \%$ & $32.8 \%$ \\
Ukupno & $1,255,392$ & $8.9 \%$ & $17.2 \%$ \\
\hline
\end{tabular}

Source: http://blog.truecar.com/2012/07/26/july-2012-newcar-sales-expected-to-be-highest-july-since-2007-accordingto-truecar-com/

- The MARKETING MIX Cluster that includes the features of a product, i.e. vehicles, the price, its promotion and distribution. (According to a comparative analysis carried out by the competition, to:http://wot.motortrend.com/2012-geneva-2013-fiat5001-looks-ready-to-tackle-the-mini-countryman176827.html)

- The ALTERNATIVES Cluster, which makes the possible levels of sale: low (below the expected lower limit of 25,000 vehicles), expected (from $25,000$ to 30,000$)$ and high (35,500 and even more).

- The COMPANY Cluster, which includes the manufacturer's features which can objectively affect the sale of vehicles. In the case of the older FIAT 500 model, the factors such as the dealer network and production organization were shown to have greatly influenced the sale of 20,000 vehicles of this model in 2011, which was significantly lower than the estimated 50,000. On the other hand, it is about the automobile manufacturer of a recognizable image and identity, so it is yet another factor needing to be taken into account.
Between and within these clusters, there are interactions, i.e. impacts, which, in our opinion and on the basis of the previously mentioned studies and the available expert analysis, should be taken into consideration when comparing pairs:

- between the ENVIRONMENT cluster and the ALTERNATIVE cluster, there are two-way dependencies;

- between the MARKETING MIX cluster and the ALTERNATIVE cluster, there are two-way dependencies;

- between the MARKETING MIX cluster and the FEATURES OF THE COMPANY cluster, there are two-way dependencies;

- the MARKETING MIX cluster is under the influence of the ENVIRONMENT cluster;

- the ALTERNATIVE cluster is influenced by the FEATURES OF THE COMPANY cluster;

- a network dealer has an impact on the marketing mix as well as the customers;

- within the MARKETING MIX cluster and the ENVIRONMENT cluster, there is an internal dependency.

\section{Model results}

In Figure 1, we can see the ANP forecasting model of selling the FIAT $500 \mathrm{~L}$ automobile, whose structure forms the clusters, elements and relations between them. These relations presented by the arrows, are indicative of the direction of an influence between the model elements defined during structuring and modeling problems. Comparing the pairs of the model elements, each cluster or elements within the same cluster, or between different clusters, is normally made by using the scale of comparison ranging from 1-9 (Table 1). Pair comparisons are basic for an AHP/ANP methodology. When certain pair factors are compared, a relative importance ratio can be determined, the preference or probability of these factors, depending on a need. This ratio represents the relation between two factors being compared. In some situations, it will be a subjective assessment; in others, however, a 
comparison is possible. Such questions and answers in both directions help determine the real priorities of decision-makers, for all elements in the problem.

When assessments for each segment of the model are entered, the information is synthesized in order to achieve the general preference of alternative outcomes. This synthesis generates a report ranking the alternative (outcomes) in relation to their overall objective. The report may include a detailed ranking accounting for the manner in which each alternative is evaluated in relation to each criterion.

Since all the necessary comparisons have been done in accordance with theoretically established principles, and after performing calculations via the Superdecisions software package developed as a software application support for the ANP, the following result has been obtained in regard to the rank-determined order of alternatives:
Table 4 The resulting priorities and rank alternatives, i.e. alternative levels of sales of Fiat $500 \mathrm{~L}$

\begin{tabular}{lcccc}
\hline $\begin{array}{l}\text { Alternative } \\
\text { (sales level) }\end{array}$ & Totals & Normalized & Ideal value & Rank \\
\hline 1 Low & 0.1219 & 0.3430 & 0.9446 & 2 \\
2 Expected & 0.1290 & 0.3631 & 1.0000 & 1 \\
3 High & 0.1044 & 0.2939 & 0.8095 & 3 \\
\hline
\end{tabular}

Table 4 provides a possible sequence of alternatives according to the rank, and the obtained alternative priorities are interpreted in terms of the probability of achieving the estimated sales volume. We can see that the highest estimated probability of achieving has the expected sales volume $(36.3 \%)$, then low volume $(34.3 \%)$, and finally a high-level sales volume (29.4\%). Small differences in the percentages indicate a high level of uncertainty existing in the process of forecasting and consequently, decision-making, which

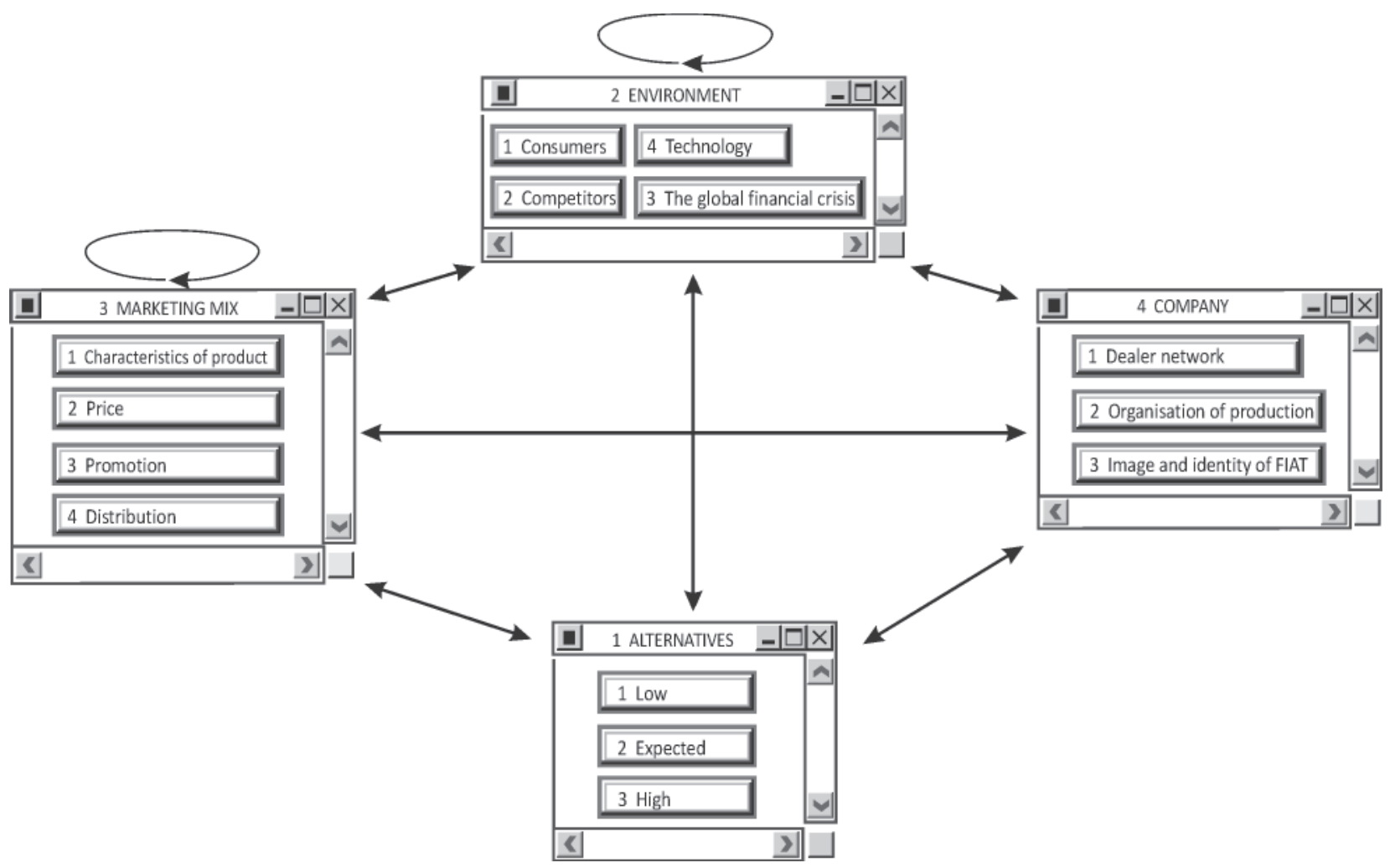

Figure 1 ANP model for forecasting sales levels of FIAT $500 \mathrm{~L}$ 
only confirms the need for an additional sensitivity analysis of the results to the changes in the value of the key model parameters, in order to obtain a complete and comprehensive assessment of the target value.

The Idealized value column shows the results divided according to the highest value, so that the highest rank has priority 1.0, while the others are in the same proportion as in Normalized value the column. The sensitivity analysis of the results by changing the level of element significance of the higher level, i.e. the register elements, may more or less significantly affect the order of importance and the evaluation of the observed options, showing what an alternative performance in terms of each criterion is, as well as how these alternatives are sensitive to changes in the decision process criteria.

Thus, Table 5 clearly accounts for the fact that the growth of the relative importance of the competition criteria, ranging from 0.0001 to 0.9999 , affects the probability of an alternative sales volume to some extent: the probability of the low level of sales increases from $34.2 \%$ to $34.6 \%$, and the probability of the expected level decreases from $36.7 \%$ to $34.2 \%$. Simultaneously, the probability of a higher level of sales increases, no matter how paradoxical it may seem, is not unusual, because actions and competitors' success are what the success of the Fiat 500 L model largely depends on.

Table 5 Sensitivity Analysis of results: The impact of changes in the relative importance of the Competitors criteria on the resulting priorities of alternatives possible levels of sales

\begin{tabular}{ccccc}
\hline $\begin{array}{c}\text { Input } \\
\text { value }\end{array}$ & $\begin{array}{c}\text { Matrix: The } \\
\text { Competition }\end{array}$ & 1 Low & 2 Expected & 3 High \\
\hline 0 & $1.00 \mathrm{E}-04$ & $3.42 \mathrm{E}-01$ & $3.67 \mathrm{E}-01$ & $2.90 \mathrm{E}-01$ \\
0.2 & $2.00 \mathrm{E}-01$ & $3.43 \mathrm{E}-01$ & $3.62 \mathrm{E}-01$ & $2.95 \mathrm{E}-01$ \\
0.4 & $4.00 \mathrm{E}-01$ & $3.44 \mathrm{E}-01$ & $3.57 \mathrm{E}-01$ & $2.99 \mathrm{E}-01$ \\
0.6 & $6.00 \mathrm{E}-01$ & $3.45 \mathrm{E}-01$ & $3.52 \mathrm{E}-01$ & $3.03 \mathrm{E}-01$ \\
0.8 & $8.00 \mathrm{E}-01$ & $3.45 \mathrm{E}-01$ & $3.47 \mathrm{E}-01$ & $3.08 \mathrm{E}-01$ \\
1 & $1.00 \mathrm{E}+00$ & $3.46 \mathrm{E}-01$ & $3.42 \mathrm{E}-01$ & $3.12 \mathrm{E}-01$ \\
\hline
\end{tabular}

Graph 3 shows the derived priorities of all the model elements just as they appear in supermatrices (the limited column). Thus, it is estimated that the dealer sales network criteria have the biggest impact on the evaluation of the alternative levels of sales (0.54445), which significantly determined the placement of the previous FIAT 500 model, only to be followed by the competition (0.48438), the global financial crisis $(0.36487)$ etc.

\section{CONCLUSION}

In the paper, one possible multiple criteria approach is suggested to forecast the sale of the new FIAT $500 \mathrm{~L}$ automobile model, based on the Analytical Network Process, as a supporting method of multi-

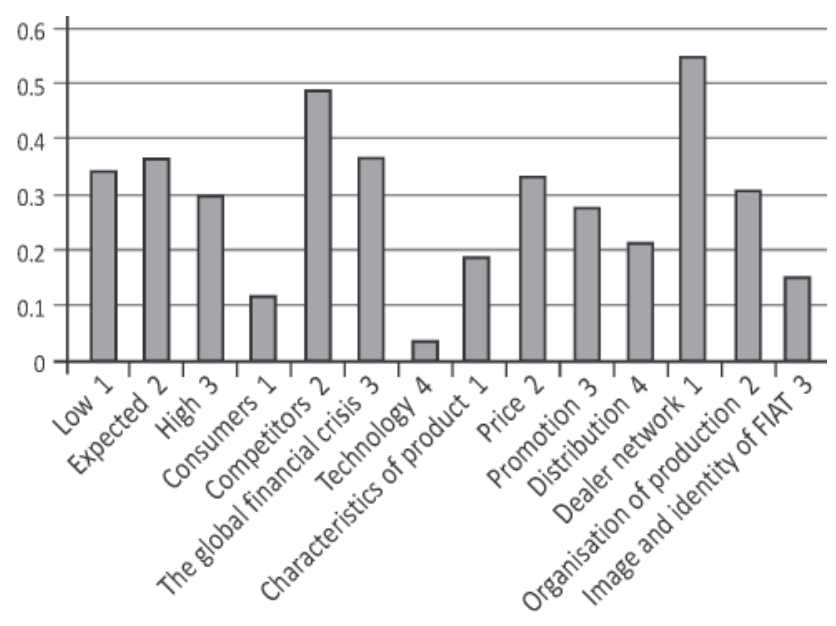

Graph 3 The resulting priorities of alternatives and criteria

criteria decision-making. The reason for this is the fact that forecasting the sales automobiles is a complex, multi-criteria problem which due to limited pieces of information and trends in the global automobile market is characterized by a high level of uncertainty. The strong competition and changes in the affinities of the purchaser, in other words -the automobile buyer, requires not only a quick response, but also the ability to forecast future trends in order to create an appropriate business strategy. In such circumstances, the existing approaches based on statistical forecasting 
methods frequently do not generate satisfactory results. Despite certain limitations, primarily related to the subjectivity of assessments and the time needed to have all these assessments performed, the ANP approach allows decision-makers to structure the influence various factors have on the final outcome of the forecasting process and to document it in a manner that can be presented to all stakeholders. The results obtained in the model are comparable and consistent with the estimated ones. More objectivity and a forecasting value would be achieved if the estimates via an ANP model are done at the management level of the FIAT corporation, which was impossible in this case; however, the validity of the results can practically be verified at the end of the forecast horizon.

The results may have their practical implications; in terms of methodological support to managers in the automotive industry, on the basis of the formal models of forecasting/decision-making, they can better understand the environment they operate in and make better strategic decisions. The theoretical implications are reflected in the fact that the confirmed effective capacity of the Analytical Network Process to conceptually include all the relevant factors out of the forecasting context/decision-making and despite usual limitations encountered during the application of qualitative forecasting methods (precision, lack of information, bias, price, etc...), can serve as a satisfactory base for the creative solution of a decisionmaking problem in situations of increasing complexity and uncertainty, when one needs to quickly make a decision.

\section{ACKNOWLEDGEMENTS}

This paper is a part of the interdisciplinary research Project (No. 41010), financed by the Ministry of Science of the Republic of Serbia

\section{REFERENCES}

Abu-Eisheh, S. A., \& Mannering, F. L. (2002). Forecasting automobile demand for economics in transition: a dynamic simultaneous equation system approach. Transportation Planning and Technology, 25(4), 311-31.

Azis, I. J. (2010). Predicting a Recovery Date from the Economic Crisis of 2008. Socio - Economic Planning Sciences, 44, 122-129.

Blair, A. R., Mnadelker, G. N., Saaty, T. L., \& Whitaker, R. (2010). Forecasting the resurgence of the U.S. economy in 2010: An expert judgment approach. Socio-Economic Planning Sciences, 44(3), 114-121.

Carlson, R. L., \& Umble, M. M. (1980). Statistical demand for automobile and their use for forecasting in an energy crises. The Journal of Business, 53(2), 193-204.

Chang, P-C., Wang, Y-W., \& Liu, C-H. (2007). The development of a weighted evolving fuzzy neural network for PCB sales forecasting. Expert Syst. Appl, 32(1), 86-96.

Dargay, J., \& Gately, D. (1999). Income's effect on car and vehicle ownership, worldwide: 1960-2015. Transport Research, 33(2), 101-38.

Fulton, G. A., Sean, A. M., Donlard, R. G., Lucie, G. S., \& Barbara, C. R. (2001). Contribution of the Automobile Industry to the US Economy in 1998: The Nation and Its Fifty States. The University of Michigan Institute of Labor and Industrial Relations, The University of Michigan Transportation Research Institute, Office for Industrial Automotive Transport and the Center for Automotive Research. Ann Arbor, MI.

Garcia-Ferrar, A., Dell, J. H., \& Martin-Arroyon, A. S. (1997). Univariate forecasting comparison: the case of the Spanish automobile industry. Journal of Forecasting, 16(1), 1-17.

Gholam-Nezhad H. (1995). The Turning Point in Oil Prices. In H. F. Didsbury, Jr. (Ed.), The Global Economy: Today, Tomorrow, and the Transition. Washington, DC: World Future Society.

Harris, E. S. (1986). Forecasting automobile output. Federal Reserve Bank of New York. Quarterly Review, 40-42.

Jharkharia, S., \& Shankar, R. (2007). Selection of logistics service provider: an analytic network process (ANP) approach. OMEGA 35(3), 274-289.

Kahn, K. (2002). An exploratory investigation of new product forecasting practices. Journal of Production and Innovation Management, 19(2), 133-143.

Karsak, E. E., Sozer, S., \& Alptekin, S. E. (2002). Product planning in quality function deployment using a combined analytic network process and goal programming approach. Computers \& Industrial Engineering, 44(1), 171-190.

Kuo, R. (2001). A sales forecasting system based on fuzzy neural network with initial weights generated by genetic algorithm. European Journal of Operational Research, 129(3), 496-517. 
Lee, J. W., \& Kim, S. H. (2000). Using analytic network process and goal programming for interdependent information system project selection. Computers \& Operations Research, 27(4), 367-382.

McAlinden, S. P., Hill, K., \& Swicki, B. (2003). Economic Contribution of Automotive Industry to the US Economy - An Update. Center for Automotive Research. Ann Arbor, MI, available at: www.cargroup.org/pdfs/Alliance-Final.pdf (accessed 20 December 2007).

Meade, L. M., \& Presley, A. (2002). R\&D project selection using the analytic network process. IEEE Transactions on Engineering Management, 49(1), 59-66.

Momoh, J. A., \& Zhu, J. (2003). Optimal generation scheduling based on AHP/ANP. IEEE Transaction on Systems Man and Cybernetics Part B-Cybernetics, 33(3), 531-535.

Niemira, P. M., \& Saaty, T. L. (2004). An Analytic Network Process model for financial-crisis forecasting. International Journal of Forecasting, 20(4), 537-587.

Plache, L. (2011). Auto Sales Forecast 2011. http://www. autoobserver.com/2011/05/16m-sales-years-beyond-2015edmunds-forecasts.html

Prevedouros, P. D., \& Ann, P. (1998). Automobile ownership in Asian countries: historical trend, and forecast. ITE Journal, 68(2), 24-29.

Romilly, P., Song, H., \& Liu, X. (1995). Modeling and forecasting car ownership in Britain. Journal of Transport Economics and Policy, 32(2),165-85.

Saaty, T. L. (2001). Decision Making with Dependence and Feedback: The Analytic Network Process. Pittsburgh: RWS Publications.

Saaty, T. L. (2005). Theory and Applications of the Analytic Network Process, Decision Making with Benefits, Opportunities, Costs and Risks. Pittsburgh: RWS Publications.
Saaty, T.(2010). Economic forecasting with tangible and intagible criteria: the analytic hierarchy process of measurement and its validation. Economic Horizons, 12(1), 5-45.

Saaty, T., \& Kearns, K. (1985). Analytical Planning: The Organization of Systems. The Analytic Hierarchy Process Series, Vol. IV.

Saaty, T., \& Vargas, L. G. (1991). Prediction, Projection and Forecasting. Kluwer Academic Publishers, Norwell.

Sarkis, J. (2003). A strategic decision framework for Green supply chain management. Journal of Cleaner Production, 11(4), 397-409.

Thomassey, S., \& Fiordaliso, A. (2006). A hybrid sales forecasting system based on clustering and decision trees. Decision Support System, 42(1), 408-421.

Vaidya, O. S., \& Kumar, S. (2006). Analytic hierarchy process: An overview of applications. European Journal of Operational Research, 169(1), 1-29.

Voulgaridou, D., Kirytopoulos, K., \& Leopoulos, V. (2009). An Analytic Network Process approach for sales forecasting. Operational Research: An International Journal, 35-53.

Yüksel, S. (2005). An Integrated Forecasting Approach for Hotels. ISAHP, Honolulu, July 8-10.

http://www.edmunds.com/about/press/strong-april-resultspush-2012-auto-sales-forecast-to-14-4-million-vehicles-saysedmundscom.html

http://blog.truecar.com/2012/07/26/july-2012-new-car-salesexpected-to-be-highest-july-since-2007-according-totruecar-com/

http://www.bloomberg.com/news/2012-02-01/fiat-industrialraises-2012-sales-forecast.html

http://www.fiat500usa.com/2012/02/fiat-500-sales-for-januarybeat-mini.html

http://www.carsitaly.net/fiat_auto.htm

\author{
Received on $7^{\text {th }}$ August 2012, \\ after one revision, \\ accepted for publication on $12^{\text {th }}$ December 2012
}

Predrag Mimovic is an associate professor at the Faculty of Economics, University of Kragujevac, Serbia. He has been teaching Operational Research and Decision Theory. He received his PhD in the multi-criteria decision making, at the Faculty of Economics, University of Kragujevac. The key areas of his research interests include multiple criteria decision making, forecasting and optimization. 


\title{
PRIMENA ANALITIČKOG MREŽNOG PROCESA U PREDVIĐANJU PRODAJE AUTOMOBILA FIAT $500 \mathrm{~L}$
}

\author{
Predrag Mimović ${ }^{*}$ \\ Ekonomski fakultet Univerziteta u Kragujevcu
}

\begin{abstract}
U radu se opisuje primena analitičkog mrežnog procesa (AMP), u modeliranju i analizi različitih faktora i uticaja na proces predviđanja, u situacijama kada postoji potreba za integracijom kontekstualnih informacija, koje su posledica iznenadnih i nepredvidivih promena u okruženju u kojem posluje preduzeće. Model je primenjen na primeru predviđanja prodaje novog modela automobila Fiat 500 L i zasniva se na ekspertskom znanju poznavalaca kretanja na tržištu automobila, postojećim stvarnim i projektovanim trendovima prodaje automobila i subjektivnim procenama autora, a u kontekstu globalne ekonomske krize koja značajno utiče na prodaju automobila na čitavom svetskom tržištu.
\end{abstract}

Ključne reči: prodaja, predviđanje, automobilska industrija, analitički mrežni proces

JEL Classification: C51, C53, D81,E27, F47

\section{UVOD}

Imajući u vidu da svetska privreda posluje u uslovima visokog rizika i neizvesnosti, uzrokovanih globalnom ekonomskom krizom, predviđanje prodaje automobila, posebno novih modela, predstavlja kompleksan, višedimenzionalan i višekriterijumskiproblem, koji zahteva i metodologiju odgovarajućeg nivoa složenosti.

Predmet istraživanja $u$ radu je mogućnost primene analitičkog mrežnog procesa (AMP), kao višekriterijumskog metoda za podršku odlučivanju u procesu predviđanja prodaje novog modela automobila Fiat $500 \mathrm{~L}$.

\footnotetext{
* Korespondencija: P. Mimović, Ekonomski fakultet Univerziteta u Kragujevcu, Đ. Pucara 3, 34000 Kragujevac, Srbija; e-mail: mimovicp@kg.ac.rs
}

Polazna hipoteza je da se postojeće projekcije i prognoze prodaje, koje su uradile stručne službe FIAT korporacije, uspešno mogu korigovati procenama dobijenim primenom AMP modela predviđanja tražnje, što bi, u krajnjoj instanci, trebalo da rezultira tačnijim predviđanjem.

Cilj istraživanja je da se integracijom i koordinacijom kontekstualnih informacija, koje se ne mogu adekvatno inkorporirati korišćenjem kvantitativnih metoda predviđanja (pre svega, vremenskih serija), smanji neizvesnost $\mathrm{i}$ stvore pretpostavke za optimizaciju procesa predviđanja na bazi primene AMP modela. Primena AMP predviđanja na primeru automobilske industrije može doprineti boljem razumevanju njenog funkcionisanja $\mathrm{u}$ globalnom okruženju, posebno $\mathrm{u}$ uslovima krize i recesije, a imajući u vidu njihovu međuzavisnost. 
Kada je u pitanju predviđanje prodaje novih proizvoda, nedostatak istorijskih informacija favorizuje primenu kvalitativnih metoda predviđanja. Važna, suštinska prednost kvalitativnih metoda predviđanja, u odnosu na kvantitativne metode predviđanja, ogleda se $u$ njihovom potencijalu da predvide promene koje mogu nastati u tražnji za novim proizvodom i, implicitno, obimu njegove prodaje.

Iako se AMP model temelji na subjektivnim procenama, karakteriše ga uspešna primena u brojnim oblastima predviđanja, sposobnost brzog inkorporiranja povratnih informacija i mogućnost jednostavne komparacije sa stvarnim rezultatima.

Struktura rada je organizovana na sledeći način: $U$ drugom delu, koji sadrži dve sekcije, dat je pregled literature koja tangira problem predviđanja prodaje automobila, uz kratak opis obrađivanih problema i korišćenih metoda predviđanja, kao i pregled relevantnih referenci vezanih za primenu analitičkog mrežnog procesa, sa posebnim osvrtom na oblast predviđanja, čime je definisan teorijsko-metodološki okvir za rešavanje posmatranog problema predviđanja. U trećem delu rada najpre je opisan AMP metod, a zatim i primenjen na konkretnoj studiji slučaja. Analitički mrežni proces se u literaturi predlaže kao rešenje za velike, dinamične i kompleksne probleme višekriterijumskog odlučivanja, kao što su strategijsko planiranje organizacionih resursa, evaluacija strategijskih alternativa i oportunost uvođenja novih proizvodnih tehnologija. Ovakvi problemi uključuju brojne, kako kvantitativne, tako i kvalitativne faktore, zatim, mnoge interaktivne atribute (ekonomske, socijalne, političke, kulturološke itd.) i kompleksne odnose između njih. Svi ovi problemi se uglavnom oslanjaju na merenje i odnose $\mathrm{u}$ procesu višekriterijumskog odlučivanja i zasnivaju se na proceni menadžerskih preferencija. Jedan takav problem je i predviđanje, koje uključuje brojne međusobno povezane i često konfliktne faktore i zavisnosti koje je potrebno uzeti u obzir, kako bi se donela optimalna poslovna odluka.

Na kraju, dati su rezultati modela zajedno sa postoptimalnom analizom, kao i zaključak, sa mogućim naznakama za buduća istraživanja.

\section{PREGLED LITERATURE}

Usled mogućih implikacija na potrošnju i ekonomiju u celini, predviđanje prodaje trajnih potrošnih dobara, kao što su automobili, ima veliki značaj, naročito ako se ima $u$ vidu da automobilska industrija ima ključnu ulogu u mnogim ekonomijama i predstavlja njihovu glavnu pokretačku snagu i generator privrednog rasta i razvoja. Potražnja za automobilima značajno utiče na trendove za putovanja i turizam, razvoj saobraćajne infrastrukture i obrasce stanovanja (Ebu-Eisheh \& Mannering, 2002), a sve ove aktivnosti doprinose privrednoj ekspanziji i otvaranju novih radnih mesta. $S$ druge strane, privredna ekspanzija vrši pritisak na političare, ekonomiste, urbaniste i saobraćajne inženjere da budu svesni trendova u potražnji automobila i da povratne informacije od njih inkorporiraju u svoje planove i projekte. Kupovina automobila je kritična potrošačka odluka koja je pod uticajem brojnih psiholoških, socioloških i ekonomskih faktora, kako $\mathrm{u}$ razvijenim zemljama, tako i u zemljama u razvoju (Abu Eisheh \& Mannering, 2002).

U pokušaju da bolje razumeju kretanje tržišta automobila i budućnost automobilske industrije, novije studije $\mathrm{i}$ analize navode tri ključna faktora koji determinišu obim prodaje automobila: platežnu sposobnost stanovništva, sposobnost zaduživanja i motivisanost za kupovinu automobila, apostrofirajući i faktor tzv. uzdržane tražnje, koji je potrebno uzeti u obzir prilikom predviđanjaprodajeautomobila, posebno nakon perioda velikih padova prodaje uzrokovanih globalnim krizama (Plache, 2011). Automobilsko tržište ima velik udeo na tržištu trajnih potrošnih dobara i kompanije koje se bave proizvodnjom automobila ne mogu da eliminišu potrebu da predvide prodaju novih modela (Kahn, 2002), bez obzira na neizvesnost koja je prisutna u razvoju i plasmanu i objektivna ograničenja, koja neretko, pored neralnih očekivanja, dovode do pogrešnih procena i velikih gubitaka.

U svojoj istraživačkoj studiji tržišta automobila, Karlson i Umble (1980) predviđaju tražnju automobila u periodu od 1979. do 1983. godine, klasifikacijom automobila u pet kategorija: pod-kompaktni, kompaktni, srednji, standard i luksuz. Autori su pokušali da utvrde prirodu odnosa cene benzina i drugih relevantnih faktora i prodaje automobila, zaključivši da je 
prodaja kompaktnih vozila porasla brže (od 35 do $45 \%)$ nego prodaja drugih vrsta automobila. Oni su, takođe, ustanovili da su ekonomski uslovi bili glavna determinanta buduće prodaje automobila. Studija je ukazala na zavisnost cene benzina i prodaje automobila. Međutim, studija je bila ograničena na dve nezavisne promenljive $u$ pokušaju da se predvidi prodaja tokom teškog političkog perioda (kriza sa taocima $u$ Iranu i naftni embargo). Iz istih razloga, Haris (1986) je, takođe, analizirao uticaj nekih ekonomskih varijabli na prodaju automobila i otkrio značajnu korelaciju potražnje i nekih ekonomskih varijabli. Garsija-Ferer i ostali (1997) koriste ARIMA model da predvide prodaju automobila, $u$ nastojanju da ocene performanse različitih metoda predviđanja. Model predviđanja nacionalnog drumskog saobraćaja (NRTF) (Romilly, 1995) uključuje model zasnovan na domaćinstvu i objašnjavajući model. Oba modela koriste kombinaciju vremenskih serija sa uključenim uzročnim varijablama. Višekriterijumski pristup $\mathrm{u}$ predviđanju prodaje predlagali su Chang et al. (2007), kroz razvoj fuzzi neuronskih mreža, Kuo (2001) i Thomassey \& Fiordaliso (2006), koji koriste klasterizaciju i stablo odlučivanja za predviđanje kompleksnosti životne sredine.

\section{Pregled AMP aplikacija}

Analitički mrežni proces (Saaty, 2001), kao ekstenzija analitičkog hijerarhijskog procesa (Saaty, 2010), može se koristiti u rešavanju problema izbora u uslovima neizvesnosti ili kao instrument za predviđanje. Problem izbora obično podrazumeva evaluaciju preferentnosti alternativnih tokova akcije dok se predviđanje primenom AHP/AMP fokusira na izvođenje distribucije relativnih verovatnoća budućih ishoda. Ova predviđanja se, zatim, koriste kada se evaluiraju alternativni tokovi akcije. Pregled AMP aplikacija objavljenih $\mathrm{u}$ naučnim časopisima (Grafikon 1), pokazuje da je najveći broj ovih aplikacija bio posvećen rešavanju problema strategijskog odlučivanja $(28 \%)$ (uglavnom problema evaluacije i izbora optimalnih poslovnih strategija i strategija lanaca snabdevanja), a u nešto manjem obimu i rešavanju političkih problema i konflikata između pojedinih zemalja i kompanija.
Uspešnu primenu analitičkog hijerarhijskog procesa i njegove ekstenzije, analitičkog mrežnog procesa, $u$ ekonomskom predviđanju demonstrirali su: Saaty (2001), Gholam-Nezhad (1995), Saaty \& GholamNezhad (1981), Blair et al (1987), Blair et al (2010), Saaty (2005), Niemira \& Saaty (2004), Yưksel (2005), Azis (2010), Voulgaridou et al (2009), itd. U prilog primeni AHP $\mathrm{u}$ predviđanju, isticane su prednosti AHP koje su se ogledale u lakoći korišćenja i velikoj mogućnosti specifikacije procena, čime se vrši provera konzistentnosti. Saaty i Vargas (1991) analiziraju primenu AHP u predviđanju cena nafte i predviđanju deviznih kurseva.

Osim toga, analitički mrežni proces se pokazao vrlo uspešnim u rangiranju i izboru projekata, što su demonstrirali Meade \& Presley (2002), kao i Lee \& Kim (2000), zatim u strategijskom odlučivanju, Sarkis (2003), i planiranju proizvodnje Karsak et al (2002), optimalnom planiranju, Momoh \& Zhu (2003) itd. Dobar pregled AHP aplikacija dali su Vaidya \& Kumar (2006). Voulgaridou et al (2009) demonstriraju primenu AMP u predviđanju prodaje novog proizvoda, naglašavajući višekriterijumsku prirodu problema i razliku između predviđanja prodaje u opštem slučaju i predviđanja prodaje novog proizvoda, koje karakteriše ograničena količina informacija, raspoloživo vreme

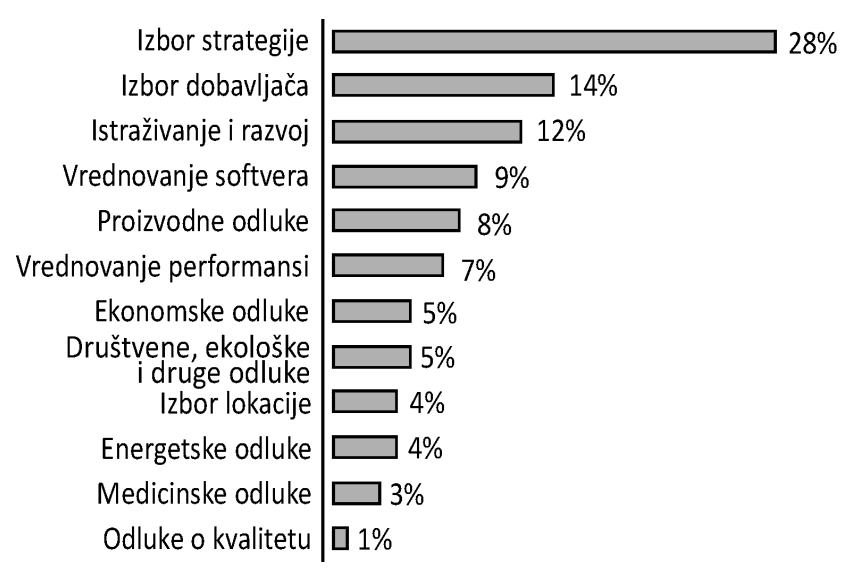

Grafikon 1 Pregled AMP aplikacija

Izvor: Voulgaridou et al, 2009, 40. 
za analizu i neizvesnost u pogledu reakcije tržišta na novi proizvod.

\section{METODOLOGIJA}

\section{Analitički mrežni proces}

Analitički mrežni proces (AMP) je metod za podršku odlučivanju koji je razvio Thomas Saaty (2001) i koji omogućuje obuhvatanje, kvantifikovanje i objektivizaciju svih relevantnih, opiplijivi i neopipiljivih faktora u procesu odlučivanja, kao i sve postojeće uticaje između kriterijuma odlučivanja i alternativa. (Jharkharia \& Shankar, 2007). Generalizujući pristup supermatrice, uveden u AHP koncept, AMP omogućuje interakcije i feedback unutar i između komponenata modela: u klasterima (unutrašnja zavisnost) i između klastera (spoljašnja zavisnost). Ovakav feedback uspešno obuhvata kompleksne veze, posebno u slučajevima rizika i neizvesnosti.

Jedan AMP model se sastoji iz dva dela. Prvi deo čine kontrolna hijerarhija ili mreža kriterijuma i podkriterijuma, koji kontrolišu interakcije u sistemu koji se proučava. Drugi deo je mreža uticaja, između elemenata i klastera, pri čemu jedan AMP model može imati jednu ili veći broj mreža. Osim toga, problem se često proučava kroz kontrolnu hijerarhiju ili sistem koji čine koristi, troškovi, mogućnosti i rizik. Sintetizovani rezultati četiri kontrolna sistema kombinuju se tako što se izračunava količnik proizvoda koristi i mogućnosti i proizvoda troškova i rizika, kako bi se determinisao najbolji ishod.

Postupak primene AMP modela odlučivanja ima pet koraka (Saaty, 2001):

- Dekompozicija problema. Problem odlučivanja se dekomponuje na njegove glavne komponente.

- Formiranje klastera za evaluaciju. Nakon definisanja ciljeva odlučivanja, neophodno je generisati i klastere za evaluaciju, i to: kriterijumski, sub-kriterijumski (ukoliko je to moguće) i klaster alternativa.

- Strukturiranje AMP modela. AMP je primenjivan na različite probleme odlučivanja u oblasti marketinga, zdravstva, politike, vojnih pitanja, društva, predviđanja itd. Njegova tačnost predviđanja pokazala se impresivnom $u$ aplikacijama $u$ oblasti ekonomskih trendova, sportskih dešavanja i drugih događaja, čiji je ishod kasnije postao poznat.

- Poređenje parova i utvrđivanje prioriteta. U ovom koraku potrebno je izvršiti poređenja parova elemenata odlučivanja, kao i sintezu prioriteta za sve alternative. Kada se vrše poređenja parova u AMP modelu, pitanja se formulišu u smislu dominacije ili uticaja, što je centralni koncept u primeni AHP/AMP metodologije. Ako je poznat kontrolni kriterijum, koji, od dva elementa koji se porede u odnosu na njega, ima veći uticaj (dominantniji je) u odnosu na taj kontrolni kriterijum? Ili, u slučaju da postoji povratna sprega, koji od ta dva elementa je pod većim uticajem kontrolnog kriterijuma? Procene se vrše prema fundamentalnoj skali 1-9 (Tabela 1), za koju je u komparativnim studijama pokazano da najadekvatnije simulira ljudsko razmišljanje.

- Analiza osetljivosti rešenja. Moguće je na kraju izvršiti i analizu osetljivosti rešenja $u$ smislu uticaja koji promena važnosti nekog kriterijuma ili podkriterijuma ima na dobijeno rešenje i konačan ishod, te posmatranjem utvrditi koliko su veliki ili mali ovi pokazatelji.

\section{Opis problema i konstrukcija AMP modela}

Model analitičkog mrežnog procesa primenjujemo na problem predviđanja prodaje novog modela automobila Fiat 500 L. Kako kažu u FIAT-u, model 500 L kombinuje karakteristikesvojstvenerazličitimklasamaautomobila, s ciljem da ponudi karakterističan i drugačiji automobil koji će biti alternativa tradicionalnim modelima B i C klase. Oznaka "L" sublimira tri ključne dimenzije, koje predstavljaju iskorak $\mathrm{u}$ odnosu na model Fiat 500: veličinu (Large), tj. veliki, funkcionalan i efikasan prostor, svetlost (Lightness), korišćenje prijateljske i ekološke tehnologije koja život čini jednostavnijim i kvalitetnijim i podešavajuće okruženje (Loft), dizajn koji omogućuje da se "život živi punim plućima". Procenjena prodaja FGA (Fiat Group Automobiles), sadržana u planu koji je predstavio S. Markione, izvršni direktor FIAT korporacije, je 2,7 miliona vozila u 2012. godini, 3,4 miliona vozila u 2013. godini i 3,8 miliona 
Tabela 1 Skala relativne važnosti koja se koristi u AHP/AMP modelima

\begin{tabular}{|c|c|c|}
\hline $\begin{array}{l}\text { Intenzitet rela- } \\
\text { tivne važnosti }\end{array}$ & Definicija & Objašnjenje \\
\hline 1 & Jednaka važnost & Dve aktivnosti jednako doprinose cilju \\
\hline 3 & $\begin{array}{l}\text { Umerena važnost jed- } \\
\text { nog u odnosu na drugi }\end{array}$ & Iskustvo i procena blago favorizuju jednu aktivnost u odnosu na drugu \\
\hline 5 & $\begin{array}{l}\text { Esencijalna ili jaka } \\
\text { važnost }\end{array}$ & Iskustvo i procena jako favorizuju jednu aktivnost u odnosu na drugu \\
\hline 7 & Demonstrirana važnost & Jedna aktivnost se jako favorizuje i njena dominacija se demonstrira u praksi \\
\hline 9 & Ekstremna važnost & $\begin{array}{l}\text { Dokazi koji favorizuju jednu aktivnost u odnosu na drugu su najvišeg mogućeg } \\
\text { reda afirmacije }\end{array}$ \\
\hline $2,4,6,8$ & $\begin{array}{l}\text { Srednje vrednosti } \\
\text { između dve susedne } \\
\text { procene }\end{array}$ & Kada je potreban kompromis \\
\hline $\begin{array}{l}\text { Reciprociteti } \\
\text { gornjih nenultih } \\
\text { brojeva }\end{array}$ & & $\begin{array}{l}\text { Ako jedna aktivnost ima jedan od gornjih brojeva (na primer, } 3 \text { ), u poređenju } \\
\text { sa drugom aktivnošću, onda druga aktivnost ima recipročnu vrednost (tj. 1/3) } \\
\text { kada se poredi sa drugom }\end{array}$ \\
\hline
\end{tabular}

Izvor: Saaty \& Kearns, 1985, 27

u 2014. godini. Glavna ciljna tržišta za 2014. godinu su evropsko, sa očekivanom prodajom od 2,15 miliona putničkih i komercijalnih vozila, Latinska Amerika sa očekivanih 1,125 milona vozila, Turska sa 90000 vozila, Kina sa 300000 vozila ( $2 \%$ udela na tržištu), Indija sa 130000 vozila (5\% udela na tržištu) i 105000 vozila (Fiat i Alfa Romeo) koji se prodaju u SAD, u produkciji CRYSLER-a.

Sredinom 2012. godine, na Sajmu automobila u Ženevi, FIAT je predstavio novi model, Fiat 500 L, koji će se serijski proizvoditi u Kragujevcu, u Republici Srbiji. Namera torinskog automobilskog giganta bila je da lansiranjem ovog modela popravi svoje pozicije na tržištu SAD, gde prodaja modela Fiat 500 ne ide po planu i gde FIAT već decenijama neuspešno pokušava da napravi prodor. Verovatno da su razlozi za neuspeh modela Fiat 500, pre svega, nerealna očekivanja, imajući $\mathrm{u}$ vidu loše pokazatelje kretanja svetske privrede koji neminovno imaju uticaja i na automobilsku indiustriju, ali i, kako se pokazalo, organizacioni problemi FIAT-a, kao što su: neadekvatna dilerska mreža, kašnjenja u proizvodnji, zakasnela marketing kampanja i loša bezbednosna ocena, što se pokazalo ključnim uzrokom relativnog neuspeha modela Fiat 500 na američkom tržištu. Podsetićemo da je projektovana proizvodnja modela Fiat $500 \mathrm{~L} u$ početku predviđena na 25000-35000 vozila godišnje, sa očekivanjem da će u 2013. godini narasti na 150000 ili 200000 automobila. Imajući u vidu da je i za stariji model Fiat 500 prvobitna prognoza bila prodaja od 50000 vozila godišnje, a da je ostvarena prodaja iznosila 20000 vozila, predviđanje prodaje novog modela očigledno ne može biti bazirano na očekivanim ili projektovanim trendovima, posebno kada se imaju u vidu organizacioni problemi s kojima se FIAT suočava, kao i osetljivost automobilske industrije na globalne ekonomske trendove. Proizvodni program putničkih i komercijalnih vozila grupacije FIAT, zaključno sa junom 2012. godine, a u odnosu na isti period u 2011. godini, zabeležio je apsolutni pad prodaje sa 929366 vozila na 839754 vozila, što je smanjenje od $9,64 \%$ (Tabela 2). S druge strane, procenjena prodaja automobila za period od 2011. godine do 2015. godine (Grafikon 2), kao i predviđanje prodaje osam najvećih svetskih proizvođača automobila za avgust mesec 2012. godine (Tabela 2), ukazuju na optimizam u proceni, koji bi se mogao objasniti pozitivnim ekonomskim trendovima u SAD, rastućom tražnjom u Kini i Indiji i očekivanjem da će se ti trendovi nastaviti i u narednom periodu, što se, takođe, ne sme zanemariti. 
Tabela 2 Kretanje mesečne prodaje putničkih i komercijalnih vozila grupacije FIAT, zaključno sa drugim kvartalom 2012.

\begin{tabular}{|c|c|c|c|c|c|c|c|c|c|c|c|c|c|}
\hline 2012 & Januar & Febr. & Mart & April & Maj & Jun & Jul & Avg. & Sep. & Okt. & Nov. & \multicolumn{2}{|c|}{ UKUPNO } \\
\hline Italija & 39.716 & 36.237 & 35.279 & 40.154 & 45.849 & 38.882 & & & & & & 236.117 & $-20,29 \%$ \\
\hline Francuska & 4.963 & 5.574 & 6.444 & 5.024 & 5.026 & 3.179 & & & & & & 33.210 & $-25,62 \%$ \\
\hline Nemačka & 5.849 & 6.055 & 9.291 & 8.370 & 9.078 & 8.595 & & & & & & 47.238 & $-9,29 \%$ \\
\hline Španija & 1.514 & 2.340 & 2.706 & 1.961 & 2.150 & 2.588 & & & & & & 13.259 & $1,89 \%$ \\
\hline V. Britanija & 3.522 & 1.724 & 10.904 & 4.529 & 4.923 & 5.647 & & & & & & 31.249 & $5,52 \%$ \\
\hline Evropa & 11.068 & 11.730 & 13.283 & 12.562 & 12.344 & 14.580 & & & & & & 75.567 & $-18,18 \%$ \\
\hline Brazil & 42.366 & 43.393 & 51.109 & 41.430 & 45.865 & 63.530 & & & & & & 287.693 & $-0,58 \%$ \\
\hline Rusija & 1.008 & 1.002 & 1.154 & 144 & 269 & 476 & & & & & & 4.053 & $-72.02 \%$ \\
\hline Indija & 2.101 & 1.704 & 1.415 & 1.000 & 1.002 & 805 & & & & & & 8.027 & $-30,71 \%$ \\
\hline Turska & 1.335 & 2.866 & 3.966 & 4.010 & 4.663 & 4.431 & & & & & & 21.271 & $-30,13 \%$ \\
\hline Meksiko & 520 & 238 & 395 & 319 & 460 & 477 & & & & & & 2.409 & $144,07 \%$ \\
\hline Argentina & 12.726 & 6.050 & 8.740 & 6.657 & 8.184 & 6.407 & & & & & & 48.761 & $12,97 \%$ \\
\hline Japan & 376 & 762 & 1.345 & 652 & 828 & 1.307 & & & & & & 5.270 & $35,06 \%$ \\
\hline SAD & 1.911 & 3.227 & 3.712 & 3.849 & 4.003 & 4.004 & & & & & & 20.706 & $318,81 \%$ \\
\hline Kanada & 321 & 533 & 1.207 & 1.211 & 810 & 839 & & & & & & 4.921 & $92,23 \%$ \\
\hline
\end{tabular}

Izvor: http://www.carsitaly.net/fiat_auto.htm

Polazeći od datih teorijskih pretpostavki i opisa problema, kao i realnog stanja okruženja, formira se odgovarajući AMP model, sa strukturom predstavljenom AMP mrežom klastera, elemenata i uticaja između njih, čija validnost je verifikovana

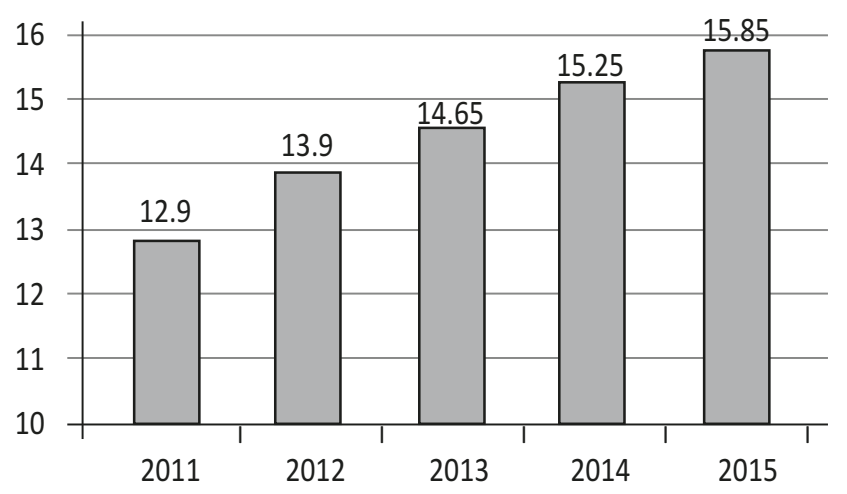

Grafikon 2 Predviđanje prodaje automobila u periodu 2011-2015.

Izvor: http://www.edmunds.com na osnovu analiza stručnjaka (koje su dostupne na internetu):

- Klaster OKRUŽENJE uključuje eksterne faktore koji mogu uticati na prodaju vozila, i to: kupci, konkurencija, globalna finansijska kriza i tehnologija. Kada se Fiat $500 \mathrm{~L}$ pojavi u prodaji početkom 2013, kako se najavljuje, imaće direktnog konkurenta u modelu Mini-Cauntryman, za koji se najavljuje da će biti sličnih dimenzija, a imaće i 20ks više.

- Klaster MARKETING MIKS koji uključuje karakteristike proizvoda, tj. vozila, cenu, promociju i distribuciju. (Prema uporednoj analizi sa konkurencijom, na: http://wot.motortrend. com/2012-geneva-2013-fiat-5001-looks-ready-totackle-the-mini-countryman-176827.html)

- Klaster ALTERNATIVE, koji čine mogući nivoi prodaje: nizak (ispod očekivane donje granice od 25000 vozila), očekivan (od 25000 do 30000) i visok (35000 i više).

- Klaster KOMPANIJA, koji uključuje karakteristike proizvođača koji objektivno mogu uticati na prodaju 
Tabela 3 Procenjena prodaja osam najvećih svetskih proizvođača automobila za avgust 2012.

\begin{tabular}{lrcc}
\hline Proizvođač & $\begin{array}{r}\text { Predviđena } \\
\text { prodaja za } \\
\text { avgust 2012. }\end{array}$ & $\begin{array}{c}\text { Promena u } \\
\text { odnosu na } \\
\text { jul 2012. }\end{array}$ & $\begin{array}{c}\text { Promena } \\
\text { u odnosu } \\
\text { na avgust } \\
2011 .\end{array}$ \\
\hline CHRYSLER & 142,593 & $13.1 \%$ & $9.6 \%$ \\
FORD & 191,456 & $10.4 \%$ & $9.5 \%$ \\
GM & 227,087 & $12.8 \%$ & $3.9 \%$ \\
HONDA & 133,458 & $14.1 \%$ & $62.1 \%$ \\
HYUNDAI/KIA & 117,212 & $6.5 \%$ & $17.6 \%$ \\
NISSAN & 97,022 & $-1.3 \%$ & $6.0 \%$ \\
TOYOTA & 182,896 & $10.9 \%$ & $41.3 \%$ \\
VOLKSWAGEN & 47,069 & $-3.4 \%$ & $32.8 \%$ \\
UKUPNO & $1,255,392$ & $8.9 \%$ & $17.2 \%$ \\
\hline
\end{tabular}

Izvor: $\quad$ http://blog.truecar.com/2012/07/26/july-2012-newcar-sales-expected-to-be-highest-july-since-2007-accordingto-truecar-com/ vozila. Kod starijeg modela Fiat 500 pokazalo se da su faktori, kao što su: dilerska mreža i organizacija proizvodnje, umnogome uticali na to da broj od 20000 prodatih vozila ovog modela u 2011. godini bude znatno manji od procenjenih 50000 . $S$ druge strane, radi se o proizvođaču automobila prepoznatljivog imidža i identiteta, pa je i to faktor koji je potrebno uzeti u obzir.

Između i unutar ovih klastera postoje interakcije, odnosno, uticaji, koje je, po našem mišljenju, a na osnovu uvida $u$ već pomenute studije $i$ dostupne stručne analize, potrebno uzeti $u$ obzir prilikom poređenja parova, i to:

- između klastera OKRUŽENJE i klastera ALTERNATIVE postoji dvosmerna zavisnost;

- između klastera MARKETING MIKS i klastera ALTERNATIVE postoji dvosmerna zavisnost;

- između klastera MARKETING MIKS i klastera KARAKTERISTIKE KOMPANIJE postoji dvosmerna zavisnost;

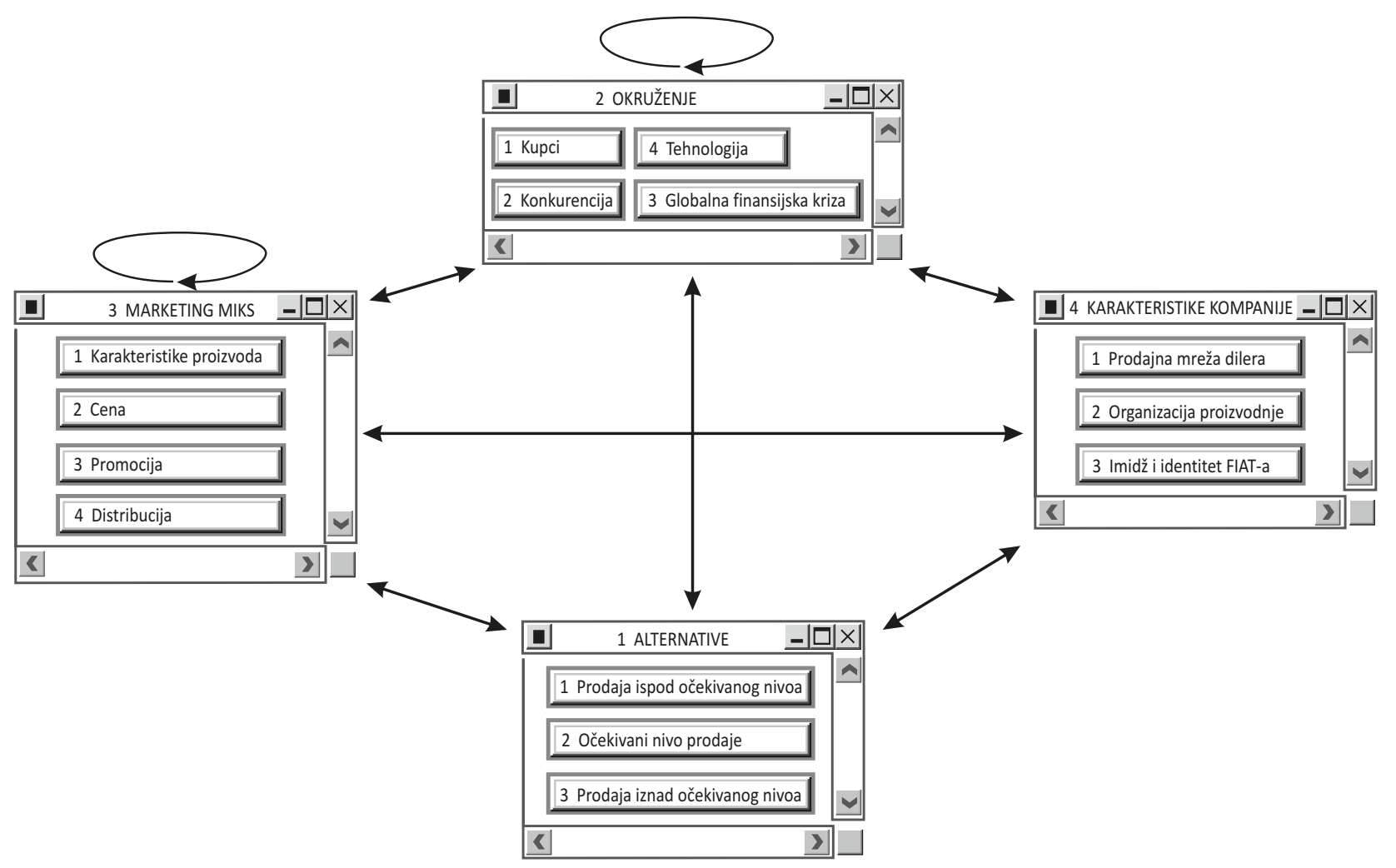

Slika 1 AMP model predviđanja nivoa prodaje automobila Fiat $500 \mathrm{~L}$ 
- klaster MARKETING MIKS je pod uticajem klastera OKRUŽENJE;

- klaster ALTERNATIVE je pod uticajem klastera KARAKTERISTIKE KOMPANIJE;

- mreža dilera ima uticaja na marketing miks, kao i na kupce;

- u okviru klastera MARKETING MIKS i klastera OKRUŽENJE postoji unutrašnja zavisnost.

\section{Rezultati modela}

Na Slici 1 vidimo AMP model predviđanja prodaje automobila Fiat 500 L, čiju strukturu čine klasteri, elementi i veze između njih. Ove veze, predstavljene strelicama, ukazuju na smer uticaja između elemenata modela utvrđenih prilikom strukturiranja i modeliranja problema. Poređenje parova elemenata modela, klastera međusobno ili elemenata u okviru istog klastera, ili između različitih klastera, vrši se uobičajeno, primenom skale poređenja 1-9 (Tabela 1). Poređenja parova su bazična za AHP/AMP metodologiju. Kada se poredi neki par faktora, može se utvrditi racio relativne važnosti, preferencija ili verovatnoća ovih faktora, $\mathrm{u}$ zavisnosti od potrebe. Ovaj racio predstavlja odnos dva faktora koji se porede. U nekim situacijama to ce biti subjektivna procena, ali u drugim je poređenje moguce. Ovakva pitanja i odgovori u oba smera pomažu da se utvrde pravi prioriteti donosioca odluka, za sve elemente $u$ problemu.

Kada se unesu procene za svaki segment modela, informacije se sintetizuju da bi se ostvarila opšta preferenca alternativnih ishoda. Ova sinteza daje izveštaj koji rangira alternative (ishode) u odnosu na opšti cilj. Izveštaj može uključiti detaljno rangiranje koje pokazuje kako je svaka alternativa evaluirana u odnosu na svaki kriterijum.

Pošto su izvršena sva potrebna poređenja u skladu sa teorijski utemeljenim principima, nakon izvršenih kalkulacija pomoću softverskog paketa Superdecisions, koji je razvijen kao softverska podrška primeni AMP, dobija se sledeći rezultat, odnosno, redosled alternativa prema rangu:
Tabela 4 Rezultirajući prioriteti i rang alternativa tj. alternativnih nivoa prodaje modela Fiat $500 \mathrm{~L}$

\begin{tabular}{lcccc}
\hline $\begin{array}{c}\text { Alternative } \\
\text { (nivoi prodaje) }\end{array}$ & Total & $\begin{array}{c}\text { Normalizova- } \\
\text { ne vrednosti }\end{array}$ & $\begin{array}{c}\text { Idealne } \\
\text { vrednosti }\end{array}$ & Rang \\
\hline 1 Nizak & 0.1219 & 0.3430 & 0.9446 & 2 \\
2 Očekivani & 0.1290 & 0.3631 & 1.0000 & 1 \\
3 Visok & 0.1044 & 0.2939 & 0.8095 & 3 \\
\hline
\end{tabular}

Tabela 4 daje mogući redosled alternativa prema rangu, a dobijene prioritete alternativa interpretiramo u smislu verovatnoće ostvarenja procenjenih obima prodaje. Vidimo da najveću procenjenu verovatnoću ostvarenja ima očekivani obim prodaje (36,3\%), zatim, nizak obim $(34,3 \%)$ i, na kraju, visok nivo $(29,4 \%)$. Male razlike $\mathrm{u}$ procentima ukazuju na visok nivo neizvesnosti koji je prisutan $u$ procesu predviđanja i, konsekventno, odlučivanja, što samo potvrđuje potrebu za dodatnim analizama osetljivosti rezultata na promene vrednosti ključnih parametara modela, kako bi se dobila potpunija i sveobuhvatnija procena ciljne vrednosti.

Kolona Idealne vrednosti pokazuje rezultate podeljene najvećom vrednošću, tako da najviši rang ima prioritet 1,0 , a ostali su u istoj proporciji kao u koloni Normalizovane vrednosti. Analiza osetljivosti rezultata promenom nivoa značajnosti elemenata višeg nivoa, $t j$. matičnih elemenata, može manje ili više značajno da utiče na redosled važnosti i ocenu posmatranih opcija, pokazujući kakva je performansa alternativa u pogledu svakog kriterijuma, kao i koliko su te alternative osetljive na promene važnosti kriterijuma.

Tako se iz Tabele 5 može videti da rast relativne važnosti kriterijuma konkurencija, od 0,0001 do 0,9999, utiče $u$ određenoj meri na verovatnoće alternativnih obima prodaje: povećava se verovatnoća niskog nivoa prodaje od $34,2 \%$ do $34,6 \%$, a smanjuje verovatnoća očekivanog nivoa sa $36,7 \%$ na $34,2 \%$. Istovremeno, povećava se verovatnoća visokog nivoa prodaje, što, ma kako paradoksalno izgledalo, nije neobično, jer od akcija i uspeha konkurenata u dobroj meri zavisi i uspeh modela FIAT $500 \mathrm{~L}$. 
Tabela 5 Uticaj promene relativne važnosti kriterijuma Konkurencija na rezultirajuće prioritete alternativa

\begin{tabular}{ccccc}
\hline $\begin{array}{c}\text { Ulazna } \\
\text { vrednost }\end{array}$ & $\begin{array}{c}\text { Matrica: } \\
\text { Konkurencija }\end{array}$ & Nizak & 2 Očekivani & 3 Visok \\
\hline 0 & $1.00 \mathrm{E}-04$ & $3.42 \mathrm{E}-01$ & $3.67 \mathrm{E}-01$ & $2.90 \mathrm{E}-01$ \\
0.2 & $2.00 \mathrm{E}-01$ & $3.43 \mathrm{E}-01$ & $3.62 \mathrm{E}-01$ & $2.95 \mathrm{E}-01$ \\
0.4 & $4.00 \mathrm{E}-01$ & $3.44 \mathrm{E}-01$ & $3.57 \mathrm{E}-01$ & $2.99 \mathrm{E}-01$ \\
0.6 & $6.00 \mathrm{E}-01$ & $3.45 \mathrm{E}-01$ & $3.52 \mathrm{E}-01$ & $3.03 \mathrm{E}-01$ \\
0.8 & $8.00 \mathrm{E}-01$ & $3.45 \mathrm{E}-01$ & $3.47 \mathrm{E}-01$ & $3.08 \mathrm{E}-01$ \\
1 & $1.00 \mathrm{E}+00$ & $3.46 \mathrm{E}-01$ & $3.42 \mathrm{E}-01$ & $3.12 \mathrm{E}-01$ \\
\hline
\end{tabular}

Grafikon 3 prikazuje dobijene prioritete svih elemenata modela onako kako se pojavljuju u supermatrici. Tako je procenjeno da će najveći uticaj za evaluaciju alternativnih nivoa prodaje imati kriterijum prodajna mreža dilera $(0,54445)$, koja je u značajnoj meri opredelila plasman prethodnog modela Fiat 500, zatim, konkurencija $(0,48438)$, globalna finansijska kriza $(0,36487)$ itd.

\section{ZAKLJUČAK}

U radu je predložen jedan mogući višekriterijumski pristup predviđanju prodaje novog modela automobila
Fiat 500 L, zasnovan na analitičkom mrežnom procesu, kao metodu za podršku višekriterjumskom odlučivanju. Razlog za to je činjenica da je predviđanje prodaje automobila kompleksan, višekriterijumski problem koji, usled limitiranih informacija i kretanja na globalnom tržištu automobila, karakteriše visok nivo neizvesnosti. Snažna konkurencija i promene $u$ afinitetima krajnjih korisnika proizvoda, odnosno, kupaca automobila, zahteva ne samo brzo reagovanje, već i sposobnost da se predvide buduća kretanja kako bi se kreirala odgovarajuća poslovna strategija. U takvim uslovima, postojeći pristupi predviđanju, bazirani na statističkim metodama, često ne daju zadovoljavajuće rezultate. Uprkos određenim ograničenjima, koja se odnose, pre svega, na subjektivnost $u$ procenama $i$ potrebno vreme da se izvrše sve procene, AMP pristup omogućuje donosiocima odluka da strukturiraju uticaj različitih faktora na konačan rezultat procesa predviđanja i dokumentuju ga tako da može biti prezentovan svim stejkholderima. Dobijeni rezultati u modelu su uporedivi i konzistentni sa procenjenim. Veća objektivnost i vrednost predviđanja bila bi postignuta da su procene primenom AMP modela izvršene na nivou menadžmenta FIAT korporacije, što $u$ ovom slučaju nije bilo moguće, ali se validnost rezultata može praktično verifikovati na kraju horizonta predviđanja.

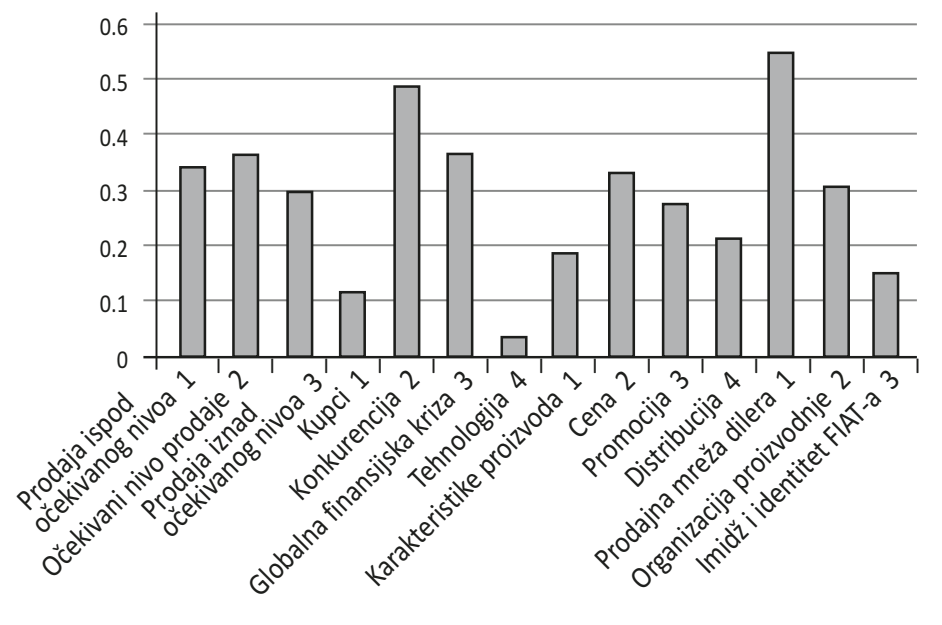

Grafikon 3 Rezultirajući prioriteti alternativa i kriterijuma 
Rezultati mogu imati praktične implikacije, u smislu metodološke podrške menadžerima $u$ automobilskoj industriji, da na bazi formalnih modela predviđanja/ odlučivanja bolje shvate okruženje u kojem posluju i donose bolje strateške odluke. Teorijske implikacije se ogledaju u činjenici da je potvrđena efektivna sposobnost analitičkog mrežnog procesa da koncepcijski obuhvati sve relevantne faktore iz konteksta predviđanja/odlučivanja i da, uprkos uobičajenim ograničenjima koja se sreću prilikom primene kvalitativnih metoda predviđanja (preciznost, nedostatak informacija, pristrasnost, cena i dr.), može poslužiti kao zadovoljavajuća osnova za kreativno rešavanje problema odlučivanja u situacijama rastuće kompleksnosti i neizvesnosti, kada je potrebno brzo doneti odluku.

\section{ZAHVALNICA}

Ovaj rad je deo Projekta integralnih i interdisciplinarnih istraživanja (br. 41010), koji finansira Ministarstvo nauke Republike Srbije.

\section{REFERENCE}

Abu-Eisheh, S. A., \& Mannering, F. L. (2002). Forecasting automobile demand for economics in transition: a dynamic simultaneous equation system approach. Transportation Planning and Technology, 25(4), 311-31.

Azis, I. J. (2010). Predicting a Recovery Date from the Economic Crisis of 2008. Socio - Economic Planning Sciences, 44, 122-129.

Blair, A. R., Mnadelker, G. N., Saaty, T. L., \& Whitaker, R. (2010). Forecasting the resurgence of the U.S. economy in 2010: An expert judgment approach. Socio - Economic Planning Sciences, 44(3), 114-121.

Carlson, R. L., \& Umble, M. M. (1980). Statistical demand for automobile and their use for forecasting in an energy crises. The Journal of Business, 53(2), 193-204.

Chang, P-C., Wang, Y-W., \& Liu, C-H. (2007). The development of a weighted evolving fuzzy neural network for PCB sales forecasting. Expert Syst. Appl, 32(1), 86-96.

Dargay, J., \& Gately, D. (1999). Income's effect on car and vehicle ownership, worldwide: 1960-2015. Transport Research, 33(2), 101-38.
Fulton, G. A., Sean, A. M., Donlard, R. G., Lucie, G. S., \& Barbara, C. R. (2001). Contribution of the Automobile Industry to the US Economy in 1998: The Nation and Its Fifty States. The University of Michigan Institute of Labor and Industrial Relations, The University of Michigan Transportation Research Institute, Office for Industrial Automotive Transport and the Center for Automotive Research. Ann Arbor, MI.

Garcia-Ferrar, A., Dell, J. H., \& Martin-Arroyon, A. S. (1997). Univariate forecasting comparison: the case of the Spanish automobile industry. Journal of Forecasting, 16(1), 1-17.

Gholam-Nezhad H. (1995). The Turning Point in Oil Prices. In H. F. Didsbury, Jr. (Ed.), The Global Economy: Today, Tomorrow, and the Transition. Washington, DC: World Future Society.

Harris, E. S. (1986). Forecasting automobile output. Federal Reserve Bank of New York. Quarterly Review, 40-42.

Jharkharia, S., \& Shankar, R. (2007). Selection of logistics service provider: an analytic network process (ANP) approach. OMEGA 35(3), 274-289.

Kahn, K. (2002). An exploratory investigation of new product forecasting practices. Journal of Production and Innovation Management, 19(2), 133-143.

Karsak, E. E., Sozer, S., \& Alptekin, S. E. (2002). Product planning in quality function deployment using a combined analytic network process and goal programming approach. Computers $\mathcal{E}$ Industrial Engineering, 44(1), 171-190.

Kuo, R. (2001). A sales forecasting system based on fuzzy neural network with initial weights generated by genetic algorithm. European Journal of Operational Research, 129(3), 496-517.

Lee, J. W., \& Kim, S. H. (2000). Using analytic network process and goal programming for interdependent information system project selection. Computers \& Operations Research, 27(4), 367-382.

McAlinden, S. P., Hill, K., \& Swicki, B. (2003). Economic Contribution of Automotive Industry to the US Economy - An Update. Center for Automotive Research. Ann Arbor, MI, available at: www.cargroup.org/pdfs/Alliance-Final.pdf (accessed 20 December 2007).

Meade, L. M., \& Presley, A. (2002). R\&D project selection using the analytic network process. IEEE Transactions on Engineering Management, 49(1), 59-66.

Momoh, J. A., \& Zhu, J. (2003). Optimal generation scheduling based on AHP/ANP. IEEE Transaction on Systems Man and Cybernetics Part B-Cybernetics, 33(3), 531-535.

Niemira, P. M., \& Saaty, T. L. (2004). An Analytic Network Process model for financial-crisis forecasting. International Journal of Forecasting, 20(4), 537-587. 
Plache, L. (2011). Auto Sales Forecast 2011. http://www. autoobserver.com/2011/05/16m-sales-years-beyond-2015edmunds-forecasts.html

Prevedouros, P. D., \& Ann, P. (1998). Automobile ownership in Asian countries: historical trend, and forecast. ITE Journal, 68(2), 24-29.

Romilly, P., Song, H., \& Liu, X. (1995). Modeling and forecasting car ownership in Britain. Journal of Transport Economics and Policy, 32(2),165-85.

Saaty, T. L. (2001). Decision Making with Dependence and Feedback: The Analytic Network Process. Pittsburgh: RWS Publications.

Saaty, T. L. (2005). Theory and Applications of the Analytic Network Process, Decision Making with Benefits, Opportunities, Costs and Risks. Pittsburgh: RWS Publications.

Saaty, T.(2010). Economicforecasting with tangibleand intagible criteria: the analytic hierarchy process of measurement and its validation. Economic Horizons, 12(1), 5-45.

Saaty, T., \& Kearns, K. (1985). Analytical Planning: The Organization of Systems. The Analytic Hierarchy Process Series, Vol. IV.

Saaty, T., \& Vargas, L. G. (1991). Prediction, Projection and Forecasting. Kluwer Academic Publishers, Norwell.

Sarkis, J. (2003). A strategic decision framework for Green supply chain management. Journal of Cleaner Production, 11(4), 397-409.
Thomassey, S., \& Fiordaliso, A. (2006). A hybrid sales forecasting system based on clustering and decision trees. Decision Support System, 42(1), 408-421.

Vaidya, O. S., \& Kumar, S. (2006). Analytic hierarchy process: An overview of applications. European Journal of Operational Research, 169(1), 1-29.

Voulgaridou, D., Kirytopoulos, K., \& Leopoulos, V. (2009). An Analytic Network Process approach for sales forecasting. Operational Research: An International Journal, 35-53.

Yüksel, S. (2005). An Integrated Forecasting Approach for Hotels. ISAHP, Honolulu, July 8-10.

http://www.edmunds.com/about/press/strong-april-resultspush-2012-auto-sales-forecast-to-14-4-million-vehicles-saysedmundscom.html

http://blog.truecar.com/2012/07/26/july-2012-new-car-salesexpected-to-be-highest-july-since-2007-according-totruecar-com/

http://www.bloomberg.com/news/2012-02-01/fiat-industrialraises-2012-sales-forecast.html

http://www.fiat500usa.com/2012/02/fiat-500-sales-for-januarybeat-mini.html

http://www.carsitaly.net/fiat_auto.htm

Primljeno 7. avgusta 2012, nakon revizije, prihvaćeno za publikovanje 12. decembra 2012.

Predrag Mimović je vanredni profesor na Ekonomskom fakultetu Univerziteta u Kragujevcu. Doktorirao je iz oblasti višekriterijumskog odlučivanja, na Ekonomskom fakultetu Univerziteta u Kragujevcu. Izvodi nastavu iz nastavnih disciplina Operaciona istraživanja i Teorija odlučivanja. Ključne oblasti njegovog istraživačkog interesovanja su višekriterijumsko odlučivanje, predviđanje i optimizacija. 


\title{
APPLICATION OF ANALYTICAL NETWORK PROCESS IN FORECASTING AUTOMOBILE SALES OF FIAT $500 \mathrm{~L}$
}

\author{
Predrag Mimovic \\ Faculty of Economics, University of Kragujevac, Kragujevac, Serbia
}

This paper describes the application of Analytic Network Process (ANP) in the modeling and analysis of various factors and the impact on the forecasting processes in situations when there is a need for the integration of contextual information, which is the result of sudden and unpredictable changes in the environment in which the company operates. The model is applied on a sample in forecasting the sale of a new model automobile Fiat $500 \mathrm{~L}$, and is based on the professional knowledge of experts in automobile market trends, the actual current and projected trends in automobile sale and subjective evaluations of the authors, and in the context of the global economic crisis which significantly affects automobile sale in the world market.

Keywords: sale, forecasting, automotive industry, the analytical network process

JEL Classification: C51, C53, D81,E27, F47 